\title{
Metronidazole thermogel improves retention and decreases permeation through the skin
}

\author{
Elayne Karine Souto de Melo, Thalita Pedon de Araujo, José Wellithom Viturino da Silva, \\ Stephanye Carolyne Christino Chagas, Danilo César Galindo Bedor, Davi Pereira de Santana, Leila \\ Bastos Leal*
}

\author{
Center of Cosmetic and Pharmaceutical Development, NUDFAC, Department of Pharmaceutical Sciences, Federal University \\ of Pernambuco, UFPE, Recife, PE, Brazil
}

\begin{abstract}
Metronidazole (MTZ) is widely used as the standard antibiotic for the treatment of rosacea and, more recently, is being used off label in Brazilian hospitals for the treatment of wounds. Following oral administration, minimal amounts of active agent reaches the skin and side effects are strongly induced. Consequently, MTZ is currently being applied topically in order to improve the therapeutic efficacy with reduced side effects, with $\operatorname{Rozex}^{\circledR}$ (RZ) (an MTZ gelled formulation) being the only marketed product. This study examined whether the use of MTZ $0.75 \%$ from thermogel formulations could improve drug retention and reduce dermal exposure compared to that by Rozex ${ }^{\circledR}$. Following a $21 \mathrm{~h}$ permeation study, the highest total amount of MTZ permeated through the rat healthy and disturbed skin was seen with Rozex $^{\circledR}$, but similar to all formulations regardless of the skin condition. On the other hand, the amount retained in the epidermis/dermis was larger for thermogel formulations; at least 4 fold that of Rozex ${ }^{\circledR}$, when the stratum corneum was present as a barrier. In conclusion, thermogel formulations can be favorable alternatives to $\operatorname{Rozex}^{\circledR}$ for the topical application of MTZ with improved efficacy and reduced side effects.
\end{abstract}

Uniterms: Metronidazole/evaluation. Metronidazole/drug retention. Poloxamer 407. Rosacea/treatment. Dermatopharmacokinetic.

\section{INTRODUCTION}

Metronidazole (MTZ, 1-( $\beta$-hydroxyethyl)-2-methyl5 -nitroimidazole), a synthetic nitroimidazole derivative, is a known antiprotozoal and antibacterial agent. Despite 50 years of clinical use, MTZ is still considered the standard antibiotic for the treatment of anaerobic infections (Freeman, Klutman, Lamp, 1997; Löfmark, Edlund, Nord, 2010). This drug is also widely used for the treatment of rosacea, a chronic skin condition that can occur at any age but is most commonly diagnosed in women between 30 and 50 years of age (Fuller, Martin, 2012; Jelvehgari, Montazam, 2011). Meanwhile, MTZ is being used off label in Brazilian hospitals for the treatment of wounds. Following oral administration of MTZ, minimal amounts

\footnotetext{
*Correspondence: L. B. Leal. Universidade Federal de Pernambuco - UFPE. Núcleo de Desenvolvimento Farmacêutico e Cosmético - NUDFAC. Avenida Professor Arthur de Sá, s/n - Cidade Universitária, 50740-520 - Recife - PE, Brasil. Fone: + 55 (81) 3302.6594 Fone/Fax: + 55 (81) 3302.6590. E-mail: leila.leal@nudfac.com.br
}

of active agent reaches the skin and side effects are strongly induced (Yu et al., 2014). Consequently, MTZ is currently being applied topically in order to improve the therapeutic efficacy with reduced side effects of the drug, with $\operatorname{Rosex}^{\circledR}$ (RZ) (an MTZ gelled formulation) being the only marketed product (Altinyazar et al., 2005) chronic dermatosis that requires long-term therapy. Oral isotretinoin and topical and/or oral antibiotics are effective, but their usage may be limited due to sideeffects. Objective The goal of the study was to compare the efficacy of topical adapalene gel $(0.1 \%$.

The skin penetration of drugs is a complex process usually limited by the stratum corneum (SC) (Herkenne et al., 2008; Menon, Cleary, Lane, 2012). According to Braddy et al. (2015) "often, even when a topical dermatological drug product is systemically absorbed, there is no established link between the concentration of the drug in the systemic circulation and the therapeutic effect". Thus, for the evaluation of topical drug products, in addition to the in vitro release test and in vitro permeation 
study, widely used methodologies include the in vivo dermal microdialysis (DMD) and dermatopharmacokinetic (DPK) approaches. The DPK procedure (in vivo or in vitro), involves measuring drug levels in the layers of SC as a function of time post-application and post-removal of the product by a tape stripping procedure (Herkenne et al., 2006; N'Dri-Stempfer et al., 2008)multiple replicate experiments are more easily performed, and toxic compounds can be evaluated. MATERIALS AND METHODS: Ex vivo experiments on isolated pig ears were compared with in vivo studies in human volunteers. Four formulations, comprising the model drug, ibuprofen, in different propylene glycol (PG.

Taking this into consideration, the aim of this work was to develop MTZ topical thermogel products intended to decrease penetration and increase MTZ retention in disturbed or healthy skin.

\section{MATERIAL AND METHODS}

\section{Chemicals}

Metronidazole $0.75 \%$ gel $\left(\operatorname{Rozex}^{\circledR}\right)$ was obtained from Galderma (Alby-sur-Chéran, France). For the tandem mass spectrometry (LC-MS/MS) analysis, metronidazole D4 was used as an internal standard (generously provided byUMR-S1070 INSERM, Poitiers, France). All chemicals used were of analytical grade and solvents were of highperformance liquid chromatography (HPLC) grade.

\section{Solubility study}

For pre-formulation study, the solubility of MTZ was determined in different solvents and systems: water, propylene glycol (PG), poloxamer 407 (P407) gel, PG/water $(1: 10, \mathrm{v} / \mathrm{v})$, and PG/P407 gel $(1: 10, \mathrm{v} / \mathrm{v})$. An excess amount of metronidazole was added to $5 \mathrm{~mL}$ of each medium and the suspensions were incubated in a shaker at $25{ }^{\circ} \mathrm{C}$ for $72 \mathrm{~h}$. After this period, the supernatant solutions were centrifuged at $605 \times g$ for $30 \mathrm{~min}$. Subsequently, the solutions were filtered and the concentration determined by HPLC-UV.

\section{Topical formulations development}

MTZ $0.75 \%$ thermogels with and without PG $10 \%$, F11 and F12 respectively, were prepared by poloxamer dispersion (15\%) using an adjustment of the cold method (Schmolka, 1972). First, MTZ, methylparaben (0.1\%), propylparaben $(0.05 \%)$, and disodium EDTA $(0.1 \%)$ were dissolved in water at $75{ }^{\circ} \mathrm{C}$ under magnetic stirring, with the exception of F11 (MTZ dissolved in PG). Next, the magnetic stirring was stopped and the $\mathrm{P} 407$ was added at $25{ }^{\circ} \mathrm{C}$. The formulations were kept at $4{ }^{\circ} \mathrm{C}$ until clean solutions were obtained.

\section{Rheological analysis}

For the rheological behavior evaluation, a RI:2:M-H Rheology International viscometer (Rheology International Shannon, Shannon, Ireland) was used. Measurements of dynamic viscosity $(\eta)$ were carried out at $37^{\circ} \mathrm{C}$ (normal body temperature) for each formulation (15g per sample), at shear rates $(\gamma)$ between 2 and $200 \mathrm{~s}^{-1}$ (Ricci et al., 2002; Ricci et al., 2005).

\section{Sol-gel transition temperature}

The sol-gel transition temperature was measured by a concentric cylinder rotational rheometer (Anton Paar MCR 500, Graz, Austria), using Rheoplus ${ }^{\circledR}$ software (v. 3.40, Anton Paar, Graz, Austria) to collect and analyze data.

The temperature of the thermogels was increased from $20{ }^{\circ} \mathrm{C}$ to $45^{\circ} \mathrm{C}$ at a heating rate of $1.0^{\circ} \mathrm{C} / \mathrm{min}$; the storage modulus (G') and the loss modulus (G”) were obtained. A graph of G' and G" versus temperature was plotted and the temperature transition was defined as where the points of G' and G" overlapped on the curve (Jiang et al., 2016).

Another technique used to determine the sol-gel transition temperature was the visual method. One gram of each formulation was placed in a respective glass tube and they were immersed in a water bath simultaneously with a separate glass tube containing $1.0 \mathrm{~mL}$ of water. A thermometer was placed in the tube with water. Slowly, the temperature of the water bath was increased and at each degree of variation the glass tube was tipped to an angle of $90^{\circ}$. The gelation temperature $(\mathrm{t} 1)$ was noted when the solution in the former stopped flowing at $90^{\circ}$. Next, the temperature of the water bath was decreased and the temperature (t2) at which the gel flowed again was determined. The sol-gel transition temperature was calculated by the mean \pm S.D. of $\mathrm{t} 1$ and $\mathrm{t} 2$ (Ur-Rehman, Tavelin, Gröbner, 2011).

\section{In vitro permeation study and Dermatopharmacokinetic evaluation}

The in vitro amount of MTZ permeated through rat skin, healthy or disturbed by tape stripping, was evaluated using Franz-type diffusion cells (Vision ${ }^{\circledR}$ Microette automated diffusion test system, Chatsworth, USA). The rat skin was obtained by excision after euthanasia with 
a lethal dose of isoflurane and posteriorly frozen at -20 ${ }^{\circ} \mathrm{C}$. This phase of the work was carried out in accordance with Ethics Committee on Animal Experimentation of the Federal University of Pernambuco under agreement n. 23076.050654/2015-91. For the disturbed skin, stratum corneum was removed following excision using 30 adhesive tapes (Scotch Book Tape 845, 3M, St. Paul, $\mathrm{MN})$. For the experiments, the skin was thawed at room temperature and placed on a donor chamber (diffusion area of $1.77 \mathrm{~cm}^{2}$ ). Approximately $166 \mathrm{mg}$ of each formulation (corresponding to $0.70 \mathrm{mg} / \mathrm{cm}^{2}$ of MTZ) was applied to the skin. The receiver chamber (volume of $6 \mathrm{~mL}$ ) was filled with a phosphate buffer solution ( $\mathrm{pH} 7.4)$, placed in a circulation water bath $\left(36^{\circ} \mathrm{C}\right)$, and agitated in a magnetic stirrer $(300 \mathrm{rpm})$. Aliquots $(1.0 \mathrm{~mL})$ were withdrawn at appropriate time intervals (between $1.0 \mathrm{~h}$ and $21 \mathrm{~h}$ ). They were immediately replaced with the same volume of fresh receptor. The collected samples were analyzed at the end of the experiment ( $21 \mathrm{~h}$ ) by LC-MS/MS.MTZ concentration in the $\mathrm{SC}$ was determined by sequential removal of the outer skin layer by tape stripping using 30 strips one-by-one (Scotch Book Tape, 3M, St. Paul, MN) followed by transepidermal water loss (TEWL) evaluation. Subsequently, the MTZ was extracted. To evaluate the MTZ amount retained in the rest of the epidermis and dermis (retention samples), the remaining skin was divided into small fractions and MTZ was extracted. Acetonitrile $(1.0 \mathrm{~mL})$ was added to each tube containing skin pieces or tapes. Next, the tubes were shaken for $6 \mathrm{~h}$ for MTZ extraction and analyzed by HPLC-UV.

\section{Sample analysis (DPK and retention samples)}

Determination of MTZ was performed by HPLCUV. The LC system employed was a Shimadzu High Performance Liquid Chromatography (Shimadzu, Kyoto, Japan) with the UV detector set at $320 \mathrm{~nm}$. Reversed-phase chromatography was performed on a $\mathrm{C} 18$ column $(5 \mu \mathrm{m}$, 150 x 4.60 mm ID; Shimadzu, Kyoto, Japan), and a Gemini ${ }^{\circledR}$ C18 pre-column $(5 \mu \mathrm{m}, 4$ x 3 mm ID; Phenomenex, Torrance, USA) at $35^{\circ} \mathrm{C}$. The mobile phase was a binary mixture of acetonitrile/monobasic sodium phosphate buffer $20 \mathrm{mM}$ and $\mathrm{pH} 3.0(12: 88)$ at a flow rate of $1.0 \mathrm{~mL} / \mathrm{min}$ and injection volume of $20 \mu \mathrm{L}$. This procedure was validated previously (Araújo, 2016).

\section{Sample analysis (Permeation samples)}

Determination of MTZ in permeation samples was performed by liquid chromatography coupled with the tandem mass spectrometry (LC-MS/MS) method adapted from Dubreuil (2005) by UMR-S1070 INSERM (Poitiers, France). Reversed-phase chromatography was performed on a $\mathrm{C} 18 \mathrm{Xbridge}^{\mathrm{TM}} \mathrm{BEH} 300$ column $(5 \mu \mathrm{m}, 150 \times 2.1 \mathrm{~mm}$ ID; Waters, St-Quentin en Yvelines, France). The isocratic mobile phase used was a mixture of acetonitrile/water/ formic acid $(25: 75: 0.1, \mathrm{v} / \mathrm{v} / \mathrm{v})$ at a flow rate of $0.16 \mathrm{~mL} / \mathrm{min}$. The Shimadzu LC System was connected to a SCIEX API 3000 MS/MS System operating in the turbo ion spray positive mode. The ions monitored in the multiple reaction monitoring mode (MRM) were $\mathrm{m} / \mathrm{z} 172.1$ (precursor ion: $[\mathrm{M}+\mathrm{H}]^{+}$) to $\mathrm{m} / \mathrm{z} 128$ (or 82 ) production for $\mathrm{MTZ}$ and $\mathrm{m} / \mathrm{z} 176.1$ (precursor ion: $[\mathrm{M}+\mathrm{H}]^{+}$) to $\mathrm{m} / \mathrm{z} 128$ (or 82 ) production for MTZ D4 (internal standard). Five microliters of permeation samples, standards, or controls were diluted with $45 \mu \mathrm{L}$ of internal standard $(0.05 \mathrm{ng} / \mu \mathrm{L}$ in ammonium formate $10 \mathrm{mM}) ; 20 \mu \mathrm{L}$ of this mixture was injected.

\section{RESULTS AND DISCUSSION}

\section{Obtainment of F11 and F12 gels}

MTZ thermogels (F11 and F12) were developed to facilitate drug administration on the skin and in wounds because they are in liquid form at room temperature. Following the incorporation of MTZ into the vehicle and dissolution of $\mathrm{P} 407$ by the cold method, odorless and colorless solutions (F11 and F12 formulations) were obtained at cool and room temperatures. Thermogels are free flowing liquid systems at room temperature, become gel at the phase transition temperature, and act to sustain drug release at physiological temperature (Chen et al., 2013; Dumortier et al., 2006).

P407 is an amphiphilic copolymer system consisting of ethylene oxide (PEO, hydrophilic) and propylene oxide (PPO, hydrophobic) organized in a triblock structure that promotes the obtainment of systems with thermo-reversible properties (Dumortier et al., 2006). Systems comprised of poloxamer polymers offer advantages such as sustained drug delivery, local and site-specific action, and comfort to patients (Lu et al., 2015). Poloxamer formulations have been used for topical, intranasal, ocular, and vaginal formulations, as well as for wound application (He et al., 2011; Heilmann et al., 2013; Jansen et al., 2013; Li et al., 2014; Rossi et al., 2014). This polymer presents biological compatibility, non-toxicity, good tolerability, and biodegradable properties (Lu et al., 2015).

\section{Solubility study}

Both formulations were developed with P407 15\%. Propylene glycol was added to the F11 gel in order to 
increase the solubility of MTZ in the system. Among the polyvalent alcohols, PG is the most frequently used co-solvent in products for topical application (Trommer, Neubert, 2006; Patel, Welsh, Baker, 1985). Table I shows the solubility values of MTZ at $36{ }^{\circ} \mathrm{C}$ in different media. The results show high MTZ solubility in the PG compared to the other media.

TABLE I - Solubility of metronidazole at $36^{\circ} \mathrm{C}$

\begin{tabular}{lc}
\hline Solvents & mg/mL \pm S.D. \\
\hline Water & $9.89 \pm 0.64$ \\
PG & $38.90 \pm 11.47$ \\
P407 gel & $11.75 \pm 1.13$ \\
PG/water $(1: 10, v / v)$ & $17.04 \pm 2.25$ \\
PG/P407 (1:10, v/v) & $13.96 \pm 2.35$ \\
\hline
\end{tabular}

\section{Sol-gel transition temperature}

The measure of sol-gel transition temperature is one of the main parameters to be evaluated in thermoreversible systems. The gelation of the poloxamer system occurs due to the geometric organization (packing) of the micelles formed by the dehydration of the PPO blocks, which is dependent on the temperature and critical micelle concentration (Cabana, Ait-Kadi, Juhasz, 1997; Kabanov, Batrakova, Alakhov, 2002).

Figure 1 and figure 2 show the variation of the rheological parameters, G' and G', of formulations F11 and F12 as a function of temperature. The temperature at which the transition from sol to gel phase occurs was verified to be $40.9^{\circ} \mathrm{C}$ for $\mathrm{F} 11$ and $40.6{ }^{\circ} \mathrm{C}$ for $\mathrm{F} 12$. This shows that the PG alters discreetly the sol-gel transition temperature between F11 and F12.

Using the visual method, the values obtained were $36.5 \pm 1.8^{\circ} \mathrm{C}$ for $\mathrm{F} 11$ and $34.5 \pm 1.0^{\circ} \mathrm{C}$ for F12. The visual method also verifies that the presence of PG in the F11 formulation increased the sol-gel transition temperature compared to that of F12 $(P \leq 0.05)$. Employing rheological techniques are sensible for this analysis; however, the visual method is rapid, simple, and less costly for routine laboratory measurements.

Figure 3 shows a lower viscosity for $\mathrm{F} 12$ than for F11 and Rozex ${ }^{\circledR}$ at body temperature $\left(\sim 37^{\circ} \mathrm{C}\right)$. The viscosities of F11 and Rozex ${ }^{\circledR}$ were similar. Through this data, we also determined the pseudoplastic behavior of the formulations observed; the viscosity decreases as the shear rate increases (Pereira et al., 2013; Ricci et al., 2002). It is worth adding that, in general, formulations containing P407 gels offer the advantage of thixotropic behavior.

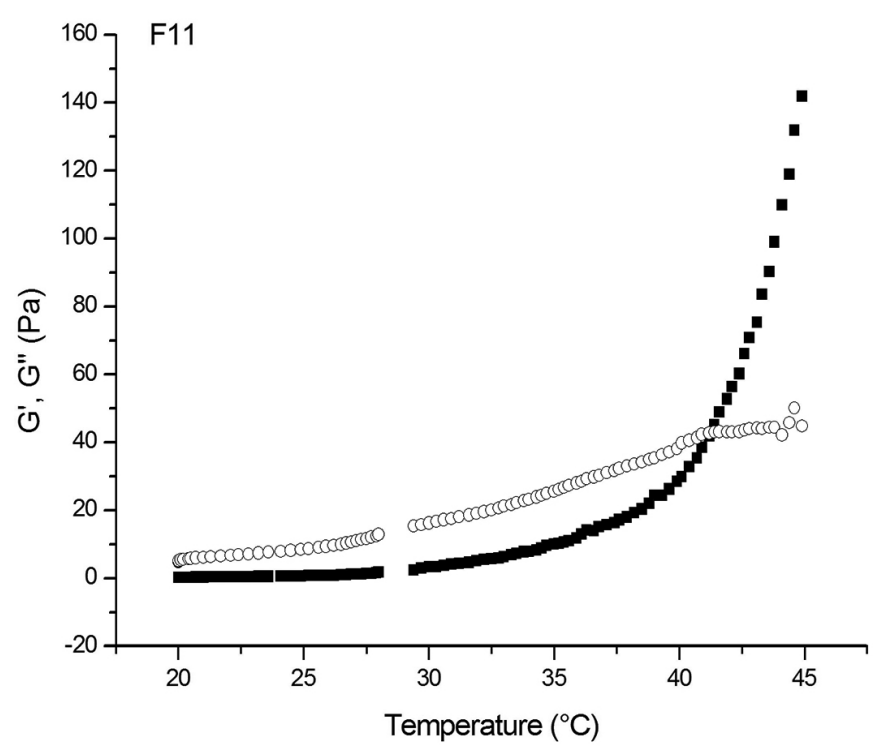

FIGURE 1 - Sol-gel transition temperature measurements for F11 gel.

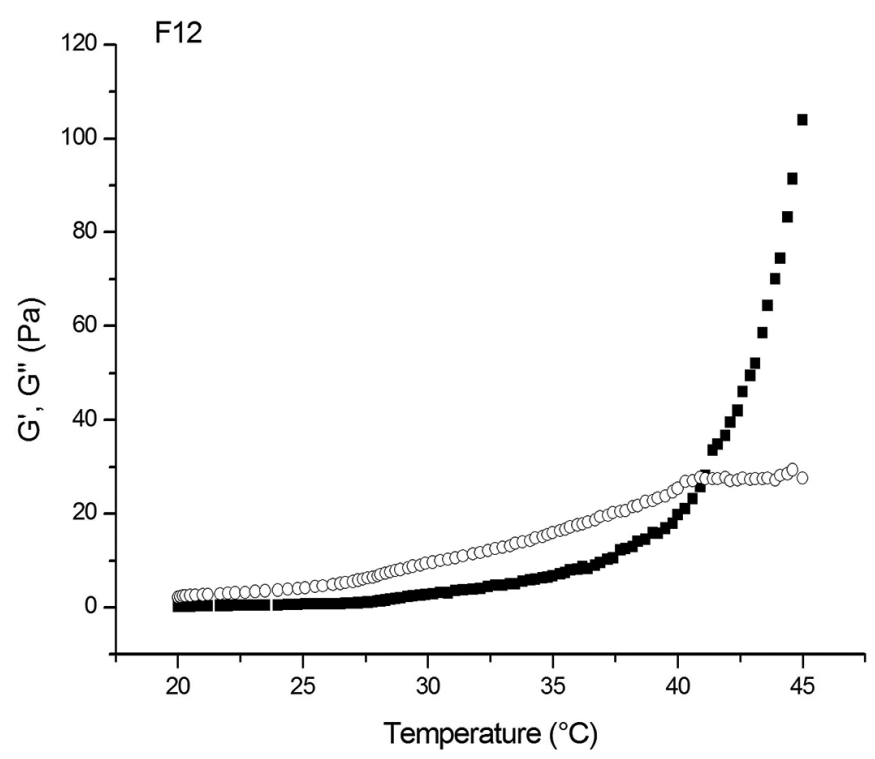

FIGURE 2 - Sol-gel transition temperature measurements for F12 gel.

This is a desirable characteristic when the intention is to facilitate the administration and spreadability in open wounds in order to avoid friction of the gel, thus reducing the suffering of the patient (Ricci et al., 2002; Pereira et al., 2013). The viscosity values apparent at $20 \mathrm{~s}^{-1}$ for the thermosensitive gels were $4.4 \mathrm{~Pa} \pm 1.2$ for the F12 gel, $6.5 \mathrm{~Pa} \pm 1.0$ for the F11 gel and 7.2 $\mathrm{Pa} \pm 0.6$ for Rozex ${ }^{\circledR}$.

Some products, when added to Poloxamer gels, have the capacity to modify their viscosity (Dumortier, 2006). The PG, included in F11 formulation, helps the dehydration of PPO blocks, making the formation of 
micelles easier. This stage precedes the gel formation of the system. Besides this, regarding Ivanova (2002), the presence of the PG decreases the lattice spacing, leading to the formation of more compact systems, culminating in the increase of the apparent viscosity of the F11 system in relation to F12 (Ivanova, Lindman, Alexandridis, 2002; Miller, Drabik, 1984; Pereira et al., 2013).

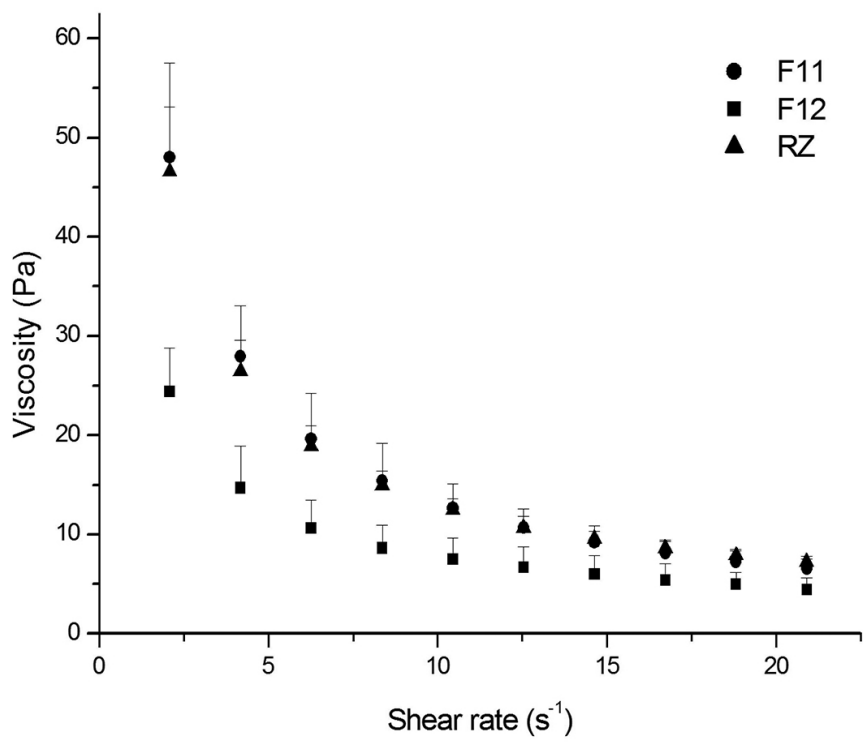

FIGURE 3 - Viscosity versus shear rate at $37^{\circ} \mathrm{C}$ of F11 gel, F12 gel, and RZ.

\section{In vitro permeation study and DPK evaluation}

Figure 4 shows the total amount $\left(\mu \mathrm{g} / \mathrm{cm}^{2}\right)$ of MTZ in $\mathrm{SC}$ from each formulation after $21 \mathrm{~h}$. The average amount of MTZ $\left(\mu \mathrm{g} / \mathrm{cm}^{2}\right)$ retained by the epidermis/dermis from healthy and disturbed skin is shown in Figure 5 and 6.

In this study (Figure 4), the statistical evaluation (test F) of the amount of MTZ in SC showed that the F11 compared to RZ, presented statistically similar results $(\mathrm{P} \geq$ $0.05)$. On the other hand, in the comparison between F12 and F11 and F12 and RZ statistically significant differences were verified $(\mathrm{P} \leq 0.05)$. In other words, a larger quantity of MTZ remained in the SC after the application of F12. The F11 and RZ formulations contain PG. According to the literature, the PG may modify the barrier properties in the SC, promoting the passage of the active drug into the skin (Patel, Welsh, Baker, 1985; Trommer, Neubert, 2006). At the same time, as a humectant, PG increases stratum corneum hydration, resulting in an increase in the drug penetration rate across the skin (Patel, Welsh, Baker, 1985).

The retention of MTZ in the epidermis/dermis in healthy skin was statistically similar for F11 vs F12

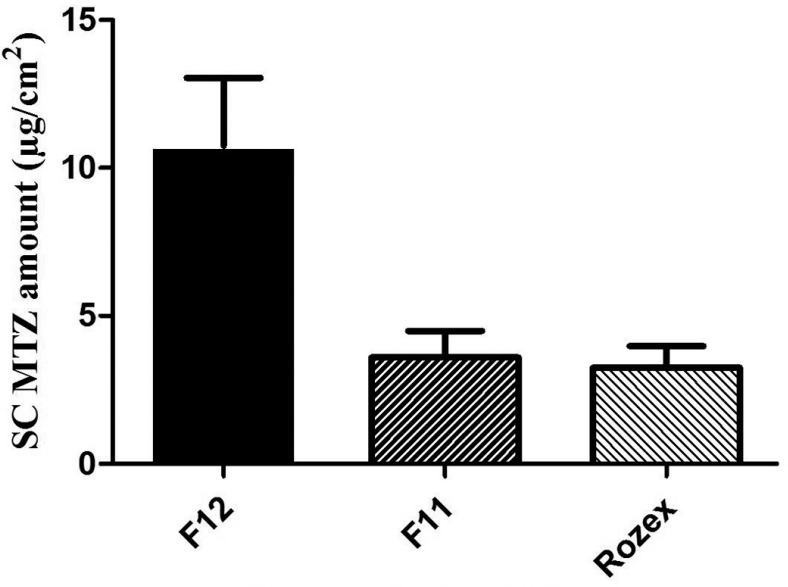

Tape stripping $21 \mathrm{~h}$

FIGURE 4 - Metronidazole amount in the stratum corneum after $21 \mathrm{~h}$.

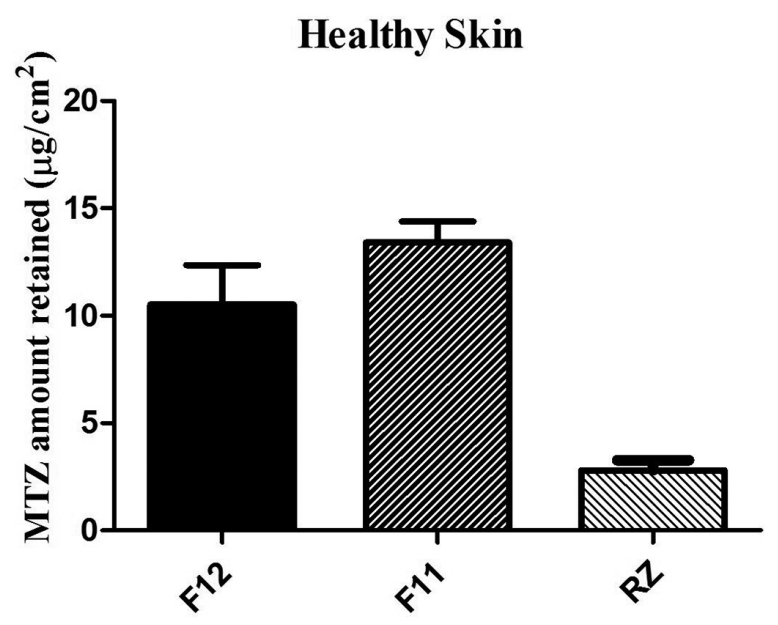

FIGURE 5 - Metronidazole amount retained in epidermis/dermis after $21 \mathrm{~h}$ - Healthy skin.

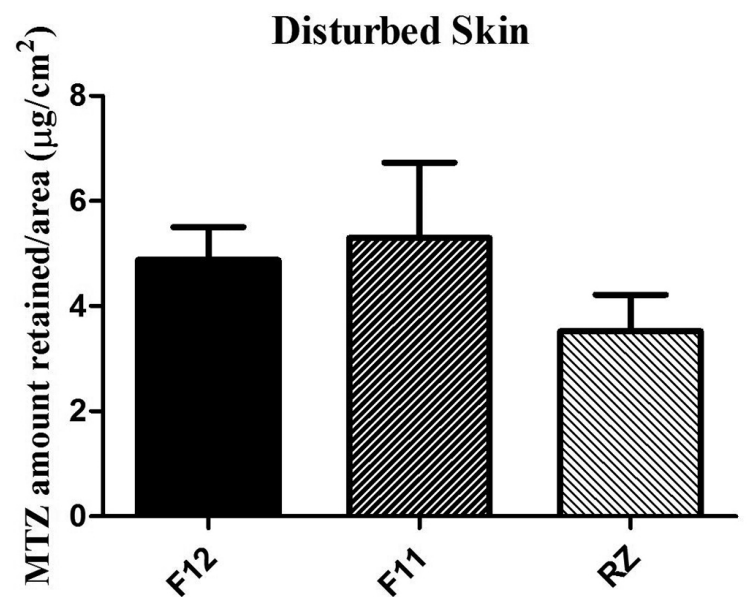

FIGURE 6 - Metronidazole amount retained in epidermis/dermis after $21 \mathrm{~h}$ - Disturbed skin. 
$(\mathrm{P} \geq 0.05)$ but different for $\mathrm{RZ}(\mathrm{P} \leq 0.05)$ (Figure 5). However, the evaluation in disturbed skin (Figure 6) showed that, comparing all formulations, the retention of MTZ was similar $(\mathrm{P} \geq 0.05)$. This data demonstrates the $\mathrm{SC}$ barrier capacity in relation to the permeation of drugs (Bolzinger et al., 2012).

A graph of the accumulated amount of MTZ permeated through skin versus time for healthy skin (Figure 7) and disturbed skin was plotted (Figure 8), and the permeation parameters were calculated (Table II). Figure 7 shows similar permeation of MTZ through healthy rat skin for $\mathrm{F} 11$ and $\mathrm{F} 12$ formulations $(\mathrm{P} \leq 0.05)$ and higher permeation for Rozex ${ }^{\circledR}$. The average amount of MTZ permeated $\left(Q_{21 \mathrm{~h}}\right)$ and the flux $(J)$ after $21 \mathrm{~h}$ for Rozex $^{\circledR}$ in healtly skin was approximately 2 and 4 -fold higher than for F11 and F12 thermogels, respectively (Table II).

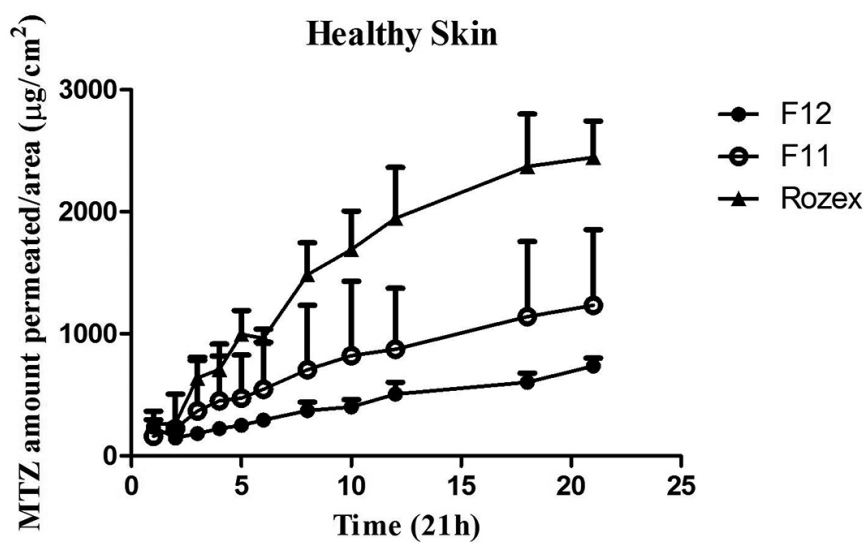

FIGURE 7 - Metronidazole amount permeated after $21 \mathrm{~h}$ Healthy skin.

As cited earlier, "poloxamer solutions have clearly indicated a micellar mode of association" (Yapar, Inal, 2012). "An important property of these aggregates is their ability to incorporate hydrophobic substances that are usually insoluble or poorly soluble (as MTZ) in aqueous or hydrophilic environment, enhancing their solubility"
(Bonacusina et al., 2008). A study carried out by Freitas et al. (2006) demonstrated that nimesulid salt, being more hydrophilic, is supposedly located on the outside of the P407 micelles. The MTZ, due to its physicochemical characteristics, is probably inserted into the micelles, leading to a smaller release of the same in poloxamer gels compared with carbopol ${ }^{\circledR}$ gel.

When comparing statistically the MTZ permeation after $21 \mathrm{~h}$ between healthy and damaged skin, no statistically significant difference was verified between the amount permeated, the flux and the $K p$ for the three formulations $(\mathrm{P} \geq 0.05)$. That is, neither the presence of PG nor the use of different polymers (P-407 e carbopol ${ }^{\circledR}$ ) in the concentration used were capable of influencing the permeation of the drug.

An in vitro permeation study of MTZ through rat skin was carried out in two models: healthy skin (Figure 7) and disturbed skin (Figure 8). For the disturbed skin, stratum corneum was removed by the tape stripping method to mimic a wound. To ensure that the entire SC was removed, the TEWL was measured (Araújo, 2016). The rat skin integrity was evaluated prior to beginning the experiments. The receptor solution was analyzed at different times up to $21 \mathrm{~h}$ and replaced with fresh solution.

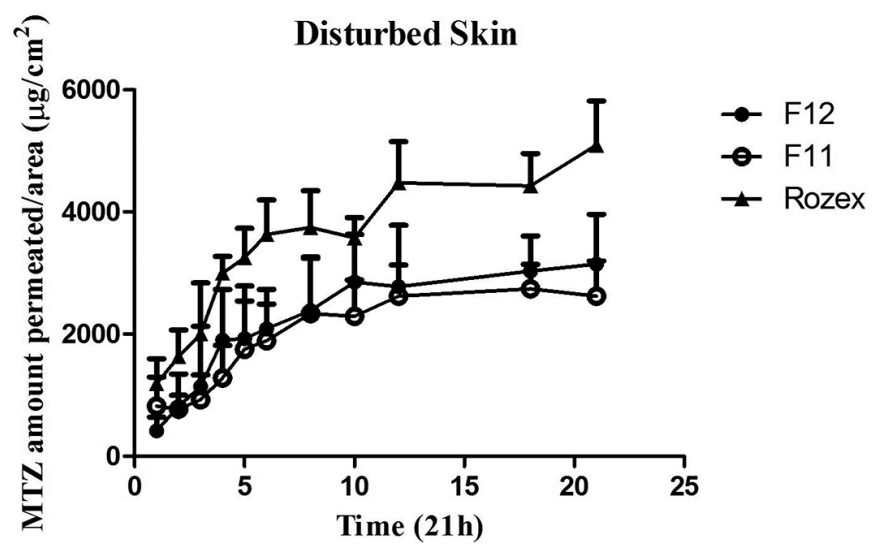

FIGURE 8 - Metronidazole amount permeated after $21 \mathrm{~h}$ Disturbed skin.

TABLE II - Permeation parameters of metronidazole in formulations

\begin{tabular}{lcccccc}
\hline \multirow{2}{*}{ Formulations } & \multicolumn{3}{c}{ Healthy skin } & \multicolumn{3}{c}{ Disturbed skin } \\
\cline { 2 - 7 } & F11 & F12 & RZ & F11 & F12 & RZ \\
\hline$Q_{21 \mathrm{~h}}{ }^{\mathrm{a}} \times 10^{2}(\mu \mathrm{g}) \pm$ S.D. & $2.19 \pm 1.09$ & $1.30 \pm 0.27$ & $4.33 \pm 1.28$ & $4.64 \pm 1.03$ & $5.57 \pm 1.44$ & $9.02 \pm 1.27$ \\
$J^{\mathrm{b}}\left(\mu \mathrm{g} / \mathrm{cm}^{2} / \mathrm{h}\right) \pm$ S.D. & $5.31 \pm 2.43$ & $2.81 \pm 0.60$ & $14.10 \pm 4.83$ & $10.20 \pm 2.34$ & $13.50 \pm 3.26$ & $16.80 \pm 2.57$ \\
$K p^{c} \times 10^{-6} \pm$ S.D. & $0.70 \pm 0.32$ & $0.37 \pm 0.07$ & $1.88 \pm 0.64$ & $1.36 \pm 0.31$ & $1.80 \pm 0.43$ & $2.24 \pm 0.34$ \\
\hline
\end{tabular}

Results are expressed as mean \pm S.D. ${ }^{a} Q_{21 \mathrm{~h}}$ : MTZ total in medium receptor after $21 \mathrm{~h} .{ }^{\mathrm{b}} J$ : MTZ flux after $21 \mathrm{~h} .{ }^{\mathrm{c}} \mathrm{Kp}$ : permeability coefficient. 
Next, the SC was analyzed using the DPK approach (N’Dri-Stempfer, 2008; Araújo, 2016) and the retention of MTZ in the epidermis and dermis was evaluated.

It is notable that the presence of PG was an important factor for improving the MTZ transport through the SC. However, this excipient was not efficient enough to increase the permeation through the whole epidermis and dermis. At the same time, the MTZ amount retained in the epidermis/dermis was larger for F11 and F12, at least 4-fold that of Rozex ${ }^{\circledR}$, when the SC was present as a barrier. Clearly, the presence of the P407 was fundamental in increasing the retention of MTZ between epidermis and dermis, thus reducing the quantity of MTZ permeated.

\section{CONCLUSION}

Considering these results, we conclude that the MTZ thermogel topical formulation can be a good alternative to improve the application and the efficacy, and to reduce the side effects due to the final characteristics of the product, to the greater retention and to the lower level of MTZ penetration through the skin. However, in order to prove this hypothesis, a clinical trial is in progress at the Instituto de Medicina Integral Professor Fernando Figueira (IMIP), Recife/PE (Brazil), and a microdialysis study in rats is being conducted for in vitro/in vivo correlation.

\section{ACKNOWLEDGEMENTS}

The authors would like to thank CAPES (Coordenação de Aperfeiçoamento de Pessoal de Nível Superior, Brazil), CNPq (Conselho Nacional de Desenvolvimento Científico e Tecnológico, Brazil), and NUDFAC/ FECDA/ UFPE (Núcleo de Desenvolvimento Farmacêutico e Cosmético/ Farmácia Escola Carlos Drummond de Andrade, Brazil) for funding this research.

\section{REFERENCES}

ALTINYAZAR, H.C.; KOCA, R.; TEKIN, N.S.; ESTÜRK, E. Adapalene vs. metronidazole gel for the treatment of rosacea. Int. J. Dermatol., v.44, n.3, p.252-255, 2005.

ARAUJO, T.P. Bioequivalência tópica de produtos contendo metronidazol através da dermatofarmacocinética (DPK). 2016. 99p. Dissertação (Mestrado) - Programa de PósGraduação em Ciências Farmacêuticas, Universidade Federal de Pernambuco, Recife, 2016.
BOLZINGER, M.A.; BRIANÇON, S.; PELLETIER, J.; CHEVALIER, Y. Penetration of drugs through skin, a complex rate-controlling membrane. Curr. Opin. Colloid Interf. Sci., v.17, n.3, p.156-165, 2012.

BONACUCINA, G.; MISICI-FALZI, M.; CESPI, M.; PALMIERI, G.F. Characterization of micellar systems by the use of acoustic spectroscopy. J. Pharm. Sci., v.97, n.6, p.2217-2227, 2008.

BRADDY, A.C.; DAVIT, B.M.; STIER, E.M.; CONNER, D.P. Survey of international regulatory bioequivalence recommendations for approval of generic topical dermatological drug products. J. Am. Assoc. Pharm. Scient., v.17, n.1, p.121-133, 2015.

CABANA, A.; AIT-KADI, A.; JUHASZ, J. Study of the gelation process of polyethylene oxide(a) polypropylene oxide(b) polyethylene oxide(a) copolymer (Poloxamer 407) aqueous solutions. J. Colloid Interf. Sci., v.190, p.307-312, 1997.

CHEN, J.; ZHOU, R.; LI, L.; LI, B.; ZHANG, X.; SU, J. Mechanical, rheological and release behaviors of a poloxamer 407/poloxamer 188/carbopol 940 thermosensitive composite hydrogel. Molecules, v.18, n.10, p.12415-12425, 2013.

DUMORTIER, G.; GROSSIORD, J.L.; AGNELY, F.; CHAUMELI, J.C. A review of poloxamer 407 pharmaceutical and pharmacological characteristics. Pharm. Res., v.23, n.12, p.2709-2728, 2006.

FREEMAN, C.D.; KLUTMAN, N.E.; LAMP, K.C. Metronidazole. A therapeutic review and update. Drugs, v.54, n.5, p.679-708, 1997.

FREITAS, M.N.; FARAH, M.; BRETAS, R.E.S.; RICCIJÚNIOR, E.; MARCHETTI, J.M. Rheological characterization of Poloxamer 407 nimesulide gels. Rev. Ciênc. Farmac. Básica Aplic., v.27, n.2, p.113-118, 2006.

FULLER, D.; MARTIN, S. Rosacea. J. Midwifery \& Women's Health, v.57, n.4, p.403-409, 2012.

HE, Z.-X; WANG, Z.-H.; ZHANG, H.-H.; PAN, X.; SU, W.-R.; LIANG, D.; WU, C.-B. Doxycycline and hydroxypropyl$\beta$-cyclodextrin complex in poloxamer thermal sensitive hydrogel for ophthalmic delivery. Acta Pharm. Sinica B, v.1, n.4, p.254-260, 2011. 
HEILMANN, S.; KÜCHLER, S.; WISCHKE, C.; LENDLEIN, A.; STEIN, C.; SCHÄFER-KORTING, M. A thermosensitive morphine-containing hydrogel for the treatment of large-scale skin wounds. Int. J. Pharm., v. 444, n.1-2, p.96-102, 2013.

HERKENNE, C.; AARTI, N.; YOGESHVAR, K.; HADGRAFT, J.; GUY, R.H. Pig ear skin ex vivo as a model for in vivo dermatopharmacokinetic studies in man. Pharm. Res., v.23, n.8, p.1850-1856, 2006.

HERKENNE, C.; ALBERTI, I.; NAIK, A.; KALIA, Y.N.; MATHY, F.-X.; PRÉAT, V.; GUY, R.H. In vivo methods for the assessment of topical drug bioavailability. Pharm. Res., v.25, n.1, p. 87-103, 2008.

IVANOVA, R.; LINDMAN, B.; ALEXANDRIDIS, P. Effect of pharmaceutically acceptable glycols on the stability of the liquid crystalline gels formed by Poloxamer 407 in water. J. Colloid Interf. Sci., v.252, n.1, p.226-235, 2002.

JANSEN, M.M.; VERZIJL, J.M. BURGER, D.M.; HEKSTER, Y.A. Controlled release of morphine from a poloxamer 407 gel. Int. J Pharm., v.452, n.1-2, p.266-269, 2013.

JELVEHGARI, M.; MONTAZAM, H. Evaluation of mechanical and rheological properties of metronidazole gel as local delivery system. Arch. Pharm. Res., v.34, n.6, p.931-940, 2011.

JIANG, Y.; MENG, X.; WU, Z.; QI, X. Modified chitosan thermosensitive hydrogel enables sustained and efficient anti-tumor therapy via intratumoral injection. Carbohydr. Polym., v.144, p.245-253, 2016.

KABANOV, A.V.; BATRAKOVA, E.V.; ALAKHOV, V.Y. Pluronic ${ }^{\circledR}$ block copolymers as novel polymer therapeutics for drug and gene delivery. J. Control. Rel., v.82, n.2-3, p.189-212, 2002.

LI, C.; LI, C.; LIU, Z.; YAN, X.; LIU, Y.; LU, W. Enhancement in bioavailability of ketorolac tromethamine via intranasal in situ hydrogel based on poloxamer 407 and carrageenan. Int. J. Pharm., v.474, n.1-2, p.123-133, 2014.

LÖFMARK, S.; EDLUND, C.; NORD, C.E. Metronidazole is still the drug of choice for treatment of anaerobic infections. Clin. Infect. Diseases, v.50, Suppl. 1, p.S16-S23, 2010.
LU, C.; LIU, M.; FU, H.; ZHANG, W.; PENG, G.; ZHANG, Y.; CAO, H.; LUO, L. Novel thermosensitive in situ gel based on poloxamer for uterus delivery. Eur. J. Pharm. Sci., v.77, p.24-28, 2015.

MENON, G.K.; CLEARY, G.W.; LANE, M.E. The structure and function of the stratum corneum. Int. J. Pharm., v.435, n.1, p.3-9, 2012.

MILLER, S.C.; DRABIK, B.R. Rheological properties of Poloxamer vehicles. Int. J. Pharm., v.18, n.3, p.269-276, 1984.

N'DRI-STEMPFER, B.; NAVIDI, W.C.; GUY, R.H.; BUNGE, A.L. Optimizing metrics for the assessment of bioequivalence between topical drug products. Pharm. Res., v.25, n.7, p.1621-1630, 2008.

PATEL, D.; WELSH, D.; BAKER, M. Comparative study of propylene glycol and caprylic/triglyceride vehicles for topical application. J. Soc. Cosmetic Chemists, v.36, n.4, p.303-311, 1985.

PEREIRA, G.G.; DIMER, F.A.; GUTERRES, S.S.; KECHINSKI, C.P.; GRANADA, J.E.; CARDOZO, N.S.M. Formulation and characterization of poloxamer $407^{\circledR}$ : Thermoreversible gel containing polymeric microparticles and hyaluronic acid. Quim. Nova, v.36, n.8, p.1121-1125, 2013.

RICCI, E.J.; BENTLEY, M.V.L.B.; FARAH, M.; BRETAS, R.E.S.; MARCHETTI, J.M. Rheological characterization of Poloxamer 407 lidocaine hydrochloride gels. Eur. J. Pharm. Sci., v.17, n.3, p.161-167, 2002.

RICCI, E.J.; LUNARDI, L.O.; NANCLARES, D.M.; MARCHETTI, J.M. Sustained release of lidocainefrom Poloxamer 407 gels. Int. J. Pharm., v.288, n.2, p.235-244, 2005.

ROSSI, S.; FERRARI, F.; BONFERONI, M.C.; SANDRI, G.; FACCENDINI, A.; PUCCIO, A.; CARAMELLA, C. Comparison of poloxamer- and chitosan-based thermally sensitive gels for the treatment of vaginal mucositis. Drug Dev. Ind. Pharm., v.40, n.3, p.352-60, 2014.

SCHMOLKA, I.R. Artificial skin I. Preparation and properties of Pluronic F-127 gels for treatments of burns. J. Biomed. Mat. Res., v.6, n.6, p.571-582, 1972. 
TROMMER, H.; NEUBERT, R.H. Overcoming the stratum corneum: the modulation of skin penetration: a review. Skin Pharmacol. Physiol., v.19, n.2, p.106-121, 2006.

UR-REHMAN, T.; TAVELIN, S.; GRÖBNER, G. Chitosan in situ gelation for improved drug loading and retention in poloxamer 407 gels. Int. J. Pharm., v.409, n.1-2, p.19-29, 2011.

YAPAR, E.; INAL, Ö. Poly(ethylene oxide)-Poly(propylene oxide)-based copolymers for transdermal drugs delivery: an overview. Trop. J. Pharm. Res., v.11, n.5, p.855-866, 2012.
YU, M.; MA, H.; LEI, M.; LI, N.; TAN, F. In vitro/in vivo characterization of nanoemulsion formulation of metronidazole with improved skin targeting and antirosacea properties. Eur. J. Pharm. Biopharm., v.88, n.1, p.92-103, 2014.

Received for publication on $07^{\text {th }}$ July 2016 Accepted for publication on $03^{\text {rd }}$ November 2016 